\title{
Da Capo: Accumulations and Explosions
}

\section{Citation}

McDonald, Christie. 2009. Da Capo: Accumulations and Explosions. In The Strange M. Proust, ed. A. Benhaïm, 86-100. London: Legenda.

\section{Permanent link}

http://nrs.harvard.edu/urn-3:HUL.InstRepos:3634142

\section{Terms of Use}

This article was downloaded from Harvard University's DASH repository, and is made available under the terms and conditions applicable to Other Posted Material, as set forth at http:// nrs.harvard.edu/urn-3:HUL.InstRepos:dash.current.terms-of-use\#LAA

\section{Share Your Story}

The Harvard community has made this article openly available.

Please share how this access benefits you. Submit a story.

Accessibility 


\title{
CHAPTER 7 \\ $*$ \\ Da capo: Accumulations and Explosions ${ }^{\mathrm{I}}$
}

\author{
Christie McDonald, Harvard University
}

In the act of reading the self through writing — Virginia Woolf called it life writing - there is part biography, part autobiography, part fiction. Proust combined them all, and created a place for the self unlike any other. Where Saint Augustine made a contingent self universal through conversion, Rousseau secularized the self in the modern confessional mode of a cogito of the senses ('I feel therefore I am'). Proust, in rejecting Sainte-Beuve's method, unfolds the meaning of the 'I' by pushing beyond Rousseau's truth-seeking fiction, identifying memory as the foundation for a self, like Nietzsche's, created. By engaging with the complexity of self-recognition, finding truth through connection to the past and to others in memory, Proust's narrator discovers enormous power.

The creation of the self as subject in narrative, like the creation of the work of art, depends on a structure of accumulation, which builds through the reiterated experiences to the very moment when the repetition of perceptions and memories is exhausted. It is then that an event explodes into meaning. Artistic models, in the analogy linking writing to music and art, provide a structure for recognizing destruction and creation as a necessary part of the fabric of the self. The search for meaning proceeds through a constant doubling of past and present: for example, memory inscribes the experience of love the way it does music.

A well-known and nevertheless enigmatic passage locates reading as an act of self-knowledge:

En réalité, chaque lecteur est quand il lit le propre lecteur de soi-même. [...] La reconnaissance en soi-même, par le lecteur, de ce que dit le livre, est la preuve de la vérité de celui-ci, et vice versa, au moins dans une certaine mesure, la différence entre les deux textes pouvant être souvent imputée non à l'auteur mais au lecteur. (Iv, 489-90)

[In reality every reader is, while he is reading, the reader of his own self. [...] And the recognition by the reader in his own self of what the book says is the proof of its veracity, the contrary also being true, at least to a certain extent, for the difference between the two texts may sometimes be imputed less to the author than to the reader.] $(3,949)$

Reading furnishes a tool for seeing what has not been previously seen, whereby the reading self is granted recognition of a hidden truth that may become conscious. Such reading both guarantees the self's truth and stands as the principle of discovery, 
announced in Le Temps retrouvé, which in a sense justifies the autobiographical exploration that has led up to it. Yet from the outset recognition, as a form of knowledge, is problematic, and it can be linked both to the central theme of the novel, writing as a vocation, and love as the most compelling and excruciatingly painful digression from art. ${ }^{2}$ Walking the line between the lessons of cumulative experience and the pitfalls of recognition, Proust experiments early on with linear sequences only to break their temporality through the dispersal of recurrent scenes when he writes the novel.

\section{Le Figaro: Accumulations}

In Contre Sainte-Beuve, Proust describes how his mother brings the newspaper Le Figaro to his room one day, and with seeming distraction and negligence puts it very near to him. The scene deals concretely with the limits of perception and the force of imagination in understanding:

Je la vis, aussitôt cela fait, sortir précipitamment de la chambre, comme un anarchiste qui a posé une bombe, et repousser dans le couloir avec une violence inaccoutumée ma vieille bonne, qui entrait précisément à ce moment-là, et qui ne comprit pas ce qui allait se passer de prodigieux dans la chambre et à quoi elle ne devait pas assister, je compris immédiatement ce que Maman avait voulu me cacher, à savoir que l'article avait paru, qu'elle ne m'en avait rien dit pour ne pas déflorer ma surprise, et qu'elle ne voulait pas que personne fût là qui pourrait troubler ma joie par sa présence, seulement m'obliger par respect humain à dissimuler. Maman n'a jamais déposé ainsi le courrier d'un air négligent près de moi, sans qu'il y eût soit un article de moi ou sur moi, ou sur quelqu'un que j'aime, soit une page de Jammes ou de Boylesve, qui sont pour moi un enchantement, soit une lettre d'une écriture aimée. (Contre Sainte-Beuve, p. 85) ${ }^{3}$

[I saw her hurry out of the room like an anarchist who had put down a bomb and, with a violence quite unlike herself, thrust back my old servant, who at that same moment was coming in, and who did not understand what this extraordinary event was that was taking place in my room, nor why she should not be present at it, I understand at once what Mamma had wished to conceal from me and knew that my article had appeared, that she had said nothing about it because she did not want to take the bloom off my surprise, and that she intended to keep out anyone whose presence might cloud my joy, or even compel me for reasons of decorum. Mamma had never put down my letters with that free-and-easy demeanour unless there had been among them either an article by me, or about me or about someone I love, or something by Jammes or Boylesve that would spell enchantment for me, or an envelope addressed in some welcome handwriting.] (By Way of Sainte-Beuve, pp. 46-47)

Much of the commentary about this passage has dealt with the relation to SaintBeuve's method, and the problem of passing from life to art. I am interested in the way in which the passage figures not so much the rupture of life into art, but the reverse: the return of art into life in the novel. As the narrator becomes his own reader, it is as though he were stepping into a minefield, a theatre of operations where anything might happen. The projection of his mother's unusually violent intent signals an act whose outcome cannot be predicted: his mother plants the 
bomb and leaves him so that joy may explode from within. This event without precedent has erotic overtones, as though his mother were setting him up for a moment of auto-erotic love ('pour ne pas déflorer ma surprise') in the experience of reading his own writing. ${ }^{4}$

But the effects are not immediate:

J'ouvris le journal. Tiens, justement un article sur le même sujet que moi! Non, mais c'est trop fort, juste les mêmes mots... Je protesterai...mais encore les mêmes mots, ma signature...c'est mon article. Mais pendant une seconde ma pensée entraînée par la vitesse acquise et peut-être déjà un peu fatiguée à cette époque continue à croire que ce n'est pas lui, comme les vieux qui continuent un mouvement commencé; mais vite je reviens à cette idée: c'est mon article' (Contre Sainte-Beuve, p. 86)

[I unfolded the copy of the Figaro. Why, here is an article on my subject! No! This is too bad, my very words... I shall write to the editor... But I said this too, and here is my name at the bottom... It is my article. But for a moment my thoughts, swept on by the impetus of this reaction, and perhaps already at this date grown rather the worse for wear, continue to believe it isn't, just as elderly people cannot arrest a movement once they have begun it. But quickly I return to the thought: it is my article!)] (By way of Sainte-Beuve, p. 47)

Recognition comes slowly. His own written words, taken in at first as those of another, are received with outrage: someone else has written on the same subject, in the same language. And even when he identifies his own signature, his reaction is delayed. It takes more than a first reading to comprehend that the writing his eyes have passed over is not someone else's. It is his own article. And with this recognition comes the sense, not so much of the truth of this writing, but of the ability to reach millions of readers. He then pretends to become another in order to understand better what is happening: 'Il faut que je sorte de soi.' And he begins anew:

Alors je prends le journal comme si je ne savais pas qu'il y a un article de moi; j'écarte exprès les yeux de l'endroit où sont mes phrases essayant de recréer ce qu'il y a plus de chance d'arriver... Je sens sur ma figure la moue de mon indifférence de lecteur non averti, puis mes yeux tombent sur mon article, au milieu, et je commence. Chaque mot m'apporte l'image que j'avais l'intention d'évoquer. A chaque phrase, dès le premier mot se dessine d'avance l'idée que je voulais exprimer; mais ma phrase me l'apporte plus nombreuse, plus détaillée, enrichie, car auteur, je suis cependant lecteur [...] et à la même idée qui se recrée en moi en ce moment, j’ai ajouté alors des prolongements symétriques, auxquels je ne pensais pas à l'instant en commençant la phrase, et qui m'émerveillent par leur ingéniosité. (Contre Sainte-Beuve, p. 86; emphasis added)

[So I pick up the Figaro as if I did not know there was an article by me in it; I purposely avert my glance from the place where the words appear, trying to discover experimentally where it would be likeliest to fall... I feel my lips purse up in the grimace of my reader who expects to find nothing in particular, then my glance falls on my article, in the centre of the page, and I begin to read. Every phrase conveys the image I meant to call up. In every sentence the thought I wanted to express is made clear from the first words; but as it comes to me in the sentence it is more abundant, more detailed, enriched - since $I$, the author, am for the time being the reader [...] and to the same thought which is now 
re-shaping itself in my mind I then added harmonious amplifications which at the sentence's beginning had not entered my head, and whose ingenuity now amazes me.] (By Way of Sainte-Beuve, pp. 47-48)

His admiration lasts only for a moment: this article is so far from his ideal that it will seem like nothing more than a 'bégaiement d'aphasique en face d'une phrase délicieuse et suivie' ['palsied stammerings [...] instead of delightfully coherent passages'] (Contre Sainte-Beuve, p. 87; By Way of Sainte-Beuve, p. 48).

The circularity of the moment is unavoidable. At the instant that publication separates him from his writing, when he should no longer need to judge himself, it is nevertheless he who still judges: 'c'est moi qui me juge!' (Contre Sainte-Beuve, p. 88). Writing for another doubles back and becomes writing to oneself. So difficult is it to believe that reality might correspond to his desire that the experience of reading the newspaper, as both writer and reader, becomes as devastating as writing to a mistress. Because he feels that no woman would write him just what he wants to read, he reins in his imagination, so that she might fill in that space and write him the very thing he wishes. By setting himself up for disappointment, as is so often the case for the protagonist of La Recherche, he is thrown back on his own desire: should she in fact write him the letter he wanted, he would believe himself to be reading a letter 'écrite par moi-même' ['I had written myself'] (Contre SainteBeuve, p. 9I; By Way of Sainte-Beuve, p. 50). The analogy of reader and mistress in this passage is one of many in Proust's work that suggest that the story of love in the Recherche (Swann and Odette, the narrator and Albertine) remains inseparable from the story of writing. In this early sketch from Contre Sainte-Beuve, however, it seems that the bomb planted by his mother failed to explode.

To understand this failure, we will look at how the passage is taken up again and dispersed into the volumes of La Recherche. There are fragmented allusions to the hero's own writing. A mention of an essay written by the narrator appears in $D u$ côté de chez Swann (I, I79), as the first writing experience, set down during the scene of 'Les clochers de Martinville.' Then in La Prisonnière, the hero rings for Françoise and picks up Le Figaro, remarking that his article is not to be found in it. But it is not until Albertine disparue (IV, I47-5I) that the scene of reading Le Figaro recurs in extended form from the pieces Proust sketched in 1908-09 and published in Contre Sainte-Beuve. In the version published in 1987 in the new Pléiade edition, his mother's terrorist intent has been submerged in a smile, indicative of the pleasure he projects her reserving for him to enjoy in solitude; the only residue of brusqueness is her gesture forcing Françoise to leave the room. The tone describing the misperception of his writing in published form is calmer, though not without effect:

J'ouvris Le Figaro. Quel ennui! Justement le premier article avait le même titre que celui que j'avais envoyé et qui n'avait pas paru. Mais pas seulement le même titre, voici quelques mots absolument pareils. Cela, c'était trop fort. J'enverrais une protestation. [...] Mais ce n'était pas quelques mots, c'était tout, c'était ma signature... C'est mon article qui avait enfin paru! (IV, I48)

[I opened the Figaro. What a bore! The main article had the same title as the article which I had sent to the paper and which had not appeared. But not merely the same title... why, here were several words that were absolutely 
identical. This was really too bad. I must write and complain. [...] But it wasn't merely a few words, it was the whole thing, and there was my signature... It was my article that had appeared at last!)] $(3,579)$

Interspersed into this version is commentary from Françoise, shocked that she, who had known him from childhood, should not be given entry to his room: 'Si ce n'est pas malheureux, un enfant qu'on a vu naître. Je ne l'ai pas vu quand sa mère le faisait, bien sûr. Mais quand je l'ai connu, pour bien dire, il n'y avait pas cinq ans qu'il était naquis!' ['It's a proper shame, a kid I saw brought into the world. I didn't see him when his mother bore him, to be sure. But when I first knew him, to say the most, it wasn't five years since he was birthed!'] (Albertine disparue, IV, I48; 3, 579). This is followed by mention of what the newspaper means to the narrator. In Combray, Swann considers spending time on the newspaper an act of trivia, compared with the few experiences in a lifetime when one reads something essential in a book: 'Du moment que nous déchirons fiévreusement chaque matin la bande du journal, alors on devrait changer les choses et mettre dans le journal, moi je ne sais pas, les... Pensées de Pascal!' [Suppose that, every morning, when we tore the wrapper off our paper with fevered hands, a transmutation were to take place, and we were to find inside - oh! I don't know; shall we say Pascal's Pensées?] (I: 26; I, 2I4). The apparent blasphemy in Swann's ironic comment becomes, when transferred to the narrator's experience of reading, a creative source. In the continuation of the passage above, the newspaper takes the place of the genius of Françoise's cooking, acknowledged early in the novel: ${ }^{5}$

Puis je considérai le pain spirituel qu'est un journal, encore chaud et humide de la presse récente ... pain miraculeux, multipliable, qui est à la fois un et dix mille, et reste le même pour chacun tout en pénétrant à la fois, innombrable, dans toutes les maisons. (IV, I48)

[Then I considered the spiritual bread of life that a newspaper is, still warm and damp from the press [...] a miraculous, self-multiplying bread which is at the same time one and ten thousand, which remains the same for each person while penetrating innumerably into every house at once.] $(3,579)$

The transport of one article to many households and readers is as miraculous as Swann's semi-serious suggestion of transforming journalistic information into quintessential revelation, in the reference to Pascal. Yet the contingency of events such as those revealed in the newspapers, founded not in an ultimate sense of truth but in secrets lodged within the humdrum of daily reality, becomes the possibility of history and self-transformation: 'la Muse qui a recueilli tout ce que les Muses plus hautes de la philosophie et de l'art ont rejeté, tout ce qui n'est pas fondé en vérité, tout ce qui n'est que contingent mais révèle aussi d'autres lois: c'est l'Histoire' [the Muse who has gathered up everything that the more exalted Muses of philosophy and art have rejected, everything that is not founded upon truth, everything that is merely contingent, but that reveals other laws as well: the Muse of History] (IV, 254; 3, 692-93). Proust disperses the scene of reading Le Figaro into the history of a life history and self-discovery so that the narrator makes way for his own creation. Music, bridging the broken connection between experience accumulated over time and the revelations of truth, serves as a guide through the labyrinths of love. 


\section{Da Capo: Love and Music}

Initially, recognition of love through a musical metaphor promises transparency:

Comme nous possédons sa chanson, gravée en nous tout entière, nous n'avons pas besoin qu'une femme nous en dise le début - rempli par l'admiration qu'inspire la beauté - pour en trouver la suite. Et si elle commence au milieu - là où les cœurs se rapprochent, où l'on parle de n'exister plus que l'un pour l'autre - nous avons assez l'habitude de cette musique pour rejoindre tout de suite notre partenaire au passage où elle nous attend. (I, I94)

[Since we know its song, which is engraved on our hearts in its entirety, there is no need for a woman to repeat the opening strains - filled with the admiration which beauty inspires - for us to remember what follows. And if she begins in the middle - where hearts are joined and where it sings of our existing, henceforward, for one another only — we are well enough attuned to that music to be able to take it up and follow our partner without hesitation at the appropriate passage.] (I, 2I 4 )

This metaphor proliferates into a sequence of musical offerings just pages later, providing the celebrated crystallization of love for Odette and Swann. The extraordinary association of love with a musical phrase depends upon Swann's prior hearing of a piece for violin and piano which he experiences as delicious and confusing (Albertine disparue, IV: 204). (Jean-Jacques Nattiez has described the stages of musical reception.) Notes come and go before they can take on any discernible meaning. As the sensations of listening pass by, Swann's mind transcribes the sensory impression: 'Ainsi à peine la sensation délicieuse que Swann avait ressentie était-elle expirée, que sa mémoire lui en avait fourni séance tenante une transcription sommaire et provisoire, mais sur laquelle il avait jeté les yeux tandis que le morceau continuait' [And so, scarcely had the exquisite sensation which Swann had experienced died away, before his memory had furnished him with an immediate transcript, sketchy, it is true, and provisional, which he had been able to glance at while the piece continued] (I, 206; I, 228). The simultaneous transcription, following the temporal linearity of the musical phrase, sets the piece in memory, so that when the musical line comes back, it can be comprehended: 'quand la même impression était tout d'un coup revenue, elle n'était déjà plus insaisissable' [when the same impression suddenly returned, it was no longer impossible to grasp] (I, 206; I, 228; emphasis added). And this creates a desire in Swann to 'see' the work again. But because he has not been able to find out who the composer is, and knows only that it is a new composition, he eventually forgets about it.

Swann first falls in love with a piece of music, as one does a person passing in the street. When he hears the music again in the salon of the Verdurin, all of a sudden ('tout d'un coup'), 'il reconnut, secrète, bruissante et divisée, la phrase aérienne et odorante qu'il aimait' [Swann [...] recognised, secret, murmuring, detached, the airy and perfumed phrase that he had loved] (Du côté de chez Swann, I, 208; I, 2303I). It was like meeting such a woman again in a friend's salon. And the narrator continues to double the evocation of woman with the piece until he learns its name: the andante of the Sonata for piano and violin by Vinteuil. Now he can possess it, 
and he tells Odette of his love for the sonata (I, 209). Unsuspecting, he does not link this composer with the person Vinteuil whom he knows, and thus confirms the implausibility of Sainte-Beuve's theory, in which understanding of the value of a work of art comes out of the life of its creator (I, 2I I). When the piano plays it again for Swann and Odette, soldering these two unlikely lovers into a single entity, a veritable country for which it serves as the national anthem, the ideal etched within this fragmentary movement (isolated by Odette as the part that is 'theirs') addresses itself to them. Swann's regret that it cannot 'know them', that it cannot be only for them a sign of the singularity of love, is a mark of the greatness of this piece which will speak to many over the centuries.

The association of Vinteuil's little phrase with love signals a change, and Swann will never again be the same, as we know. Projecting what might have been, the narrator glimpses for Swann the promise of a life rejuvenated through the discovery of what the narrator calls 'invisible realities' (I, 208), in which Swann no longer thought he believed. But no conversion, no involuntary memory equivalent to the madeleine materializes for Swann. Rather, through complex circuitry in the experience of art (Vinteuil, Botticelli, de Hooch), another person becomes attached to him: 'un être nouveau était là avec lui, adhérent, amalgamé à lui, duquel il ne pourrait peut-être pas se débarrasser, avec qui il allait être obligé d'user de ménagements comme avec un maitre ou avec une maladie' [a new person was there beside him, adhering to him, amalgamated with him, a person whom he might, perhaps, be unable to shake off, like a master or an illness] (Du côté de chez Swann, I, 225; I, 249-50; emphasis added). The new alloy, Swann-and-Odette, the uneasy merging of a self constituted by affect made intelligible, yet tortured by inexorable uncertainty, exacts instability to exist.

When later towards the end of the affair, the little phrase catches Swann off guard in Odette's absence, it substitutes for her presence and produces a suffering so intense that he covers his heart, as the place of psychical as well as physical mortality (I, 339). The refrains, replayed, evoke happiness and mourning for its loss, and the distress of a self split and reflected back at first incomprehensibly: 'Et Swann aperçut, immobile en face de ce bonheur revécu, un malheureux qui lui fit pitié parce qu'il ne le reconnut pas tout de suite, si bien qu'il dut baisser les yeux pour qu'on ne vît pas qu'ils étaient pleins de larmes. C'était lui-même' [And Swann could distinguish, standing motionless before that scene of remembered happiness, a wretched figure who filled him with such pity, because he did not at first recognise who it was, that he had to lower his eyes lest anyone should observe that they were filled with tears. It was himself] (I, 34I; I, 377). 'Seeing' this happiness through the return of the phrase, he almost cannot recognize the earlier incarnation of a self, 'un malheureux', who could not stay the same, and yet who could not change: himself. Like the narrator reading the article in Le Figaro as the work of another writer, Swann empathizes with the projection of himself. The narrator affords comprehension. When Mme Swann plays the little phrase from Vinteuil's sonata, he reflects upon the importance of repetition: 'Et pourtant quand plus tard on m'eut joué deux ou trois fois cette Sonate, je me trouvai la connaitre parfaitement' [And yet when, later on, this sonata had been played to me two or three times I found 
that I knew it perfectly well] (A l'ombre des jeunes filles en fleurs, I, 520; I, 570). The understanding that comes from 'seeing', as discovery through memory, is similar to that of 'hearing' through memory, hearing for the 'first time' what one has heard before:

Aussi n'a-t-on pas tort de dire 'entendre pour la première fois.' Si l'on n'avait vraiment [...] rien distingué à la première audition, la deuxième, la troisième seraient autant de premières. [...] Probablement ce qui fait défaut, la première fois, ce n'est pas la compréhension, mais la mémoire'. (A l'ombre des jeunes filles en fleurs, I, 520)

[And so it is not wrong to speak of hearing a thing for the first time. If one had indeed [...] received no impression from the first hearing, the second, the third would be equally 'first hearings'. [...] Probably what is wanting, the first time, is not comprehension but memory.] (I, 570)

It would seem that all innovation must in some paradoxical way be repetition of itself, as if one cannot experience newness.

When in La Prisonnière the narrator hears a musical work at Mme Verdurin's that he cannot recognize, he finds himself all of a sudden (and I will return to the importance of suddenness signalled by the words 'tout à coup') in Vinteuil's sonata retracing the phrase that so intimately connected Swann and Odette. But he is led elsewhere. By this time, the sonata is so well known that its strong emotive association is worn out for him, whereas the new piece, moving away from the pastoral candour of the sonata, bursts into red colouring like a sunrise full of mysterious hope. No dove-like sound here, no soft sound, but seven notes piercing and tearing the air violently like a rooster crowing in the morning (La Prisonnière, III, 754). It is Vinteuil's great septet, the ideal model of the work of art, evoking personal and stable colors which would in future, the narrator reflects, erupt anew each time the work is replayed (La Prisonnière, III, 758), in what he calls, in a telling oxymoron, 'durable nouveauté, enduring newness. But the curious history of this piece is that it survived only because it was transcribed by Vinteuil's daughter's friend, the one seen with her in the act of profaning her father during a Sapphic and sadistic scene, at Montjouvain. The reminder of this scene, inserted into the epiphany of the septet, shows not only that works of art exist in history, but that they come into being materially by and through the labours of dedicated individuals. It shows further the surreptitious link between the ideal work of art and the surprising consequence of lesbian love: Mlle Vinteuil's friend might have made the life of the composer painful in his last years (of which the scene at Montjouvain was but an example), but it was she who was to ensure the posterity of this work. And the narrator comments on the familial relations of people outside the legitimate bonds recognized by society: 'De relations qui ne sont pas consacrées par les lois, découlent des liens de parenté aussi multiples, aussi complexes, plus solides seulement, que ceux qui naissent du mariage' [Relations which are not sanctioned by the law establish bonds of kinship as manifold, as complex, and even more solid, than those which spring from marriage] (III, 676; 3, 263).

The reprise of certain phrases from the sonata in the septet brings with it slight changes of rhythm and accompaniment such that it is 'la même et toujours pourtant 
autre, comme reviennent les choses dans la vie' [the same and yet something else, as things recur in life] (La Prisonnière, III, 763; 3, 26I). The repeated phrases move from the single work to dispersion in place and time: this is as true of Elstir's works dispersed in museums as of Vinteuil's notes (La Prisonnière, III, 76I). Reiteration in the accumulation of experience shadows life itself. It makes change bearable. In the act of reading, on the other hand, Proust writes in a sketch, change can be tolerated because it is felt through the fiction of other peoples' lives:

Ce qui provoque notre plus grande anxiété c'est le sentiment du changement, $\mathrm{du}$ changement total non seulement des apparences mais même de notre volonté, de nos amours. Or ce sentiment nous ne l'avons jamais dans la vie, nous changeons trop lentement pour pouvoir nous en apercevoir, et quand le changement est accompli, l'état nouveau qui nous eût attristés est justement devenu le nôtre et celui que nous ne voudrions pas changer, même contre celui dont cela nous eût tant attristés de penser que nous ne le regretterions pas. Or le phénomène particulier de la lecture identifie notre volonté, nos affections avec ceux de personnages, et ceci fait, ces personnages l'auteur les fait mourir, cesser d'aimer, en un mot nous fait sentir le changement. (Esquisse XLVIII, I, 79I-92)

[What provokes our greatest anxiety is the feeling of change, the total change not only of appearances but of our own will and our love life. Now, we never get this feeling in life, we can't perceive it because of the slowness with which we change, and when the change has been made, the new state - which would have saddened us - has become our own, and the one that we would not wish to exchange, even for the state which would have been so sad to think that we would not regret. The particular phenomenon of reading identifies our will and our affections with the characters, and when this is done, the author makes them die or cease to love, in a word makes us feel the change.]

\section{Explosion}

The slowness of imperceptible change contrasts with the dislocations of time and experience through intermittency and with the explosive potential in the novel. Certain fulgurant moments are marked explicitly. In A l'ombre des jeunes filles en fleurs, the mention of Bergotte's name makes our young hero jump as if 'le bruit d'un revolver [...] a[vait] déchargé sur moi' [the sound of a revolver [had] fired at me point blank] (I, 537; I, 589). Yet the effect here is like that of a magician whose shot miraculously reveals in its trace a dove:

Ce nom de Bergotte me fit tressauter comme le bruit d'un revolver qu'on aurait déchargé sur moi, mais instinctivement pour faire bonne contenance je saluai; devant moi, comme ces prestidigitateurs qu'on aperçoit intacts et en redingote dans la poussière d'un coup de feu d'où s'envole une colombe, mon salut m'était rendu par un homme jeune, rude, petit, râblé et myope, à nez rouge en forme de coquille de colimaçon et à barbiche noire'. (A l'ombre des jeunes filles en fleurs, I, 537)

[The name Bergotte made me start, like the sound of a revolver fired at me point blank, but instinctively, to keep my countenance, I bowed: there, in front of me, like one of those conjurers whom we see standing whole and unharmed, in their frock coats, in the smoke of a pistol shot out of which a pigeon had 
just fluttered, my greeting was returned by a youngish, uncouth, thickset and myopic little man, with a red nose curled like a snail-shell and a goatee beard.] $(\mathrm{I}, 589)$

Proust is thinking of Anatole France. Later, his own exaltation (II, I73) can be violent, as is joy when it erupts not only in himself but in others: 'la joie remplissait avec une violence si soudaine leur visage translucide en un instant devenu rouge que leur bouche n'avait pas la force de la retenir et pour la laisser passer, éclatait de rire' [joy sprang with such sudden violence into their translucent faces, flushed in an instant, that their lips had not the strength to hold it in, and, to allow it to escape, parted in a burst of laughter] (II, 258; I, 966).

Others have commented on the violence of Proust's language. Genette referred to a 'détonateur analogique'; ${ }^{7}$ Deleuze to the 'violence' with which a chance encounter forces thought into being through the sign, concluding that 'what does violence to us is richer than all the fruits of our good will or of our conscious work'. And Benjamin commented on the enigma of the work in its 'paralyzing, explosive will to happiness'. 'For Sollers, violence is to be found under the surface: society is a disguised matriarchy which gradually feminizes males, just as 'la patronne' makes and unmakes reputations and couples. Dangerous hypocrisy is everywhere; knives glare under flowers; social roles of the encrusted hierarchy are eaten away through time and submission. ${ }^{\text {IO }}$ Even the narrator notices the excesses of his own violent reaction against Gomorrhe, in Andrée's behavior, for example: 'j'avais exprimé avec trop de violence mon dégoût pour ce genre de mœurs' [I had expressed with undue violence my disgust at those proclivities] (Albertine disparue I, IV, 9I; 3, 520). And rage can turn into shame or guilt, as when Albertine quotes Racine to express her intimidation at his anger: 'Hélas! Sans frissonner quel $c<œ>$ ur audacieux / Soutiendrait les éclairs qui partent de vos yeux' [Alas! Without a tremble what bold heart / Could withstand the lightning from your eyes] (La Prisonnière, III, 897).

Jeanne Proust writes to Marcel in I897 concerning a Venetian glass that he had broken: 'Le verre cassé ne sera plus que ce qu'il est au temple - le symbole de l'indissoluble union' (Correspondance, II, I60, letter 9I). In Jean Santeuil, Jean breaks a Venetian glass because he cannot repress his anger, and trembling, he then grabs one of his mother's dresses in gestures described as both violent and sexual (the cloth 'meurtri par la violence du coup' is like a woman whom a warrior has grabbed by the hair; and the touch and smell of the velvet remind him of embracing his mother). To conclude this passage, Proust quotes his mother's letter: 'Le verre cassé ne sera plus que ce qu'il est au temple - le symbole de l'indissoluble union' [It shall be, as in the Temple, the symbol of an indestructible union] (Jean Santeuil [I952], III, 3I5; 2I8). (The word temple, unlike synagogue or église, could be considered an acceptable Christian euphemism, common at the time, by which Mme Proust alludes to the Jewish marriage ceremony and the breaking of a glass marking the moment that seals the marriage.) This expansion of his mother's expression to an entire scene in Jean Santeuil contains within it both incestuous eroticism and violence.

Proust replants his mother's explosive not only in the relationship of the self to writing, but also in describing the chaotic connection of oneself to another person. In the Recherche he recounts his hero's wrath about the relationship to Albertine, a 
result of the impossibility of knowing her: 'C'est terrible d'avoir la vie d'une autre personne attachée à la sienne comme une bombe qu'on tiendrait sans qu'on puisse la lâcher sans crime' [It is terrible to have the life of another person attached to one's own like a bomb which one holds in one's hands, unable to get rid of it without committing a crime] (La Prisonnière, III, 686; 3, I79). ${ }^{\text {II }}$ Just as Swann and Odette were amalgamated in a love that might not have been, were it not for an analogy to art, so the narrator finds himself enmeshed with Albertine, repeating the destiny of love. The threat of annihilation to the self from detonation (not only in separation but in the continuation of the affair as well) puts both lover and mistress at high risk. Everything, from the family to sexual mores and social rank, may explode, leaving fractured a world that the narrator still holds dear. Benjamin situates this capacity for breaking everything into shards at a sociological level $(2,32 \mathrm{I})$. So it is that, in mourning Albertine's death, the mere mention of a name associated with her - a street or road, or simply a phrase — can provoke violent shocks of unimaginable pain (IV, II8). The repetitive structures in love resurface in dreams and reinforce the painful misapprehensions between lovers, joyless memories associated neither with writing nor music.

It is through the power of return in memory to a time and a place in dreaming and a doubling effect, rather than a 'reality' of the other, that the narrator explicitly evokes the musical sign indicating repetition from the beginning:

Souvent c'était tout simplement pendant mon sommeil que ces 'reprises,' ces da capo du rêve tournant d'un seul coup plusieurs pages de la mémoire, plusieurs feuillets du calendrier, me ramenaient, me faisaient rétrograder à une impression douloureuse mais ancienne, qui depuis longtemps avait cédé la place à d'autres et qui redevenait présente. (Albertine disparue, IV, II9)

[Often it was simply during my sleep that these 'reprises,' these 'da capos' of one's dreams, which turn back several pages of one's memory, several leaves of the calendar at once, brought me back, made me regress to a painful but remote impression which had long since given place to others but which now became present once more.] $(3,549 \text {; emphasis added })^{12}$

The narrator taunts the reader with a parodic da capo of reading when our hero says to Gilberte, quoting Mme de Cambremer: 'Relisez ce que Schopenhauer dit de la musique' [reread what Schopenhauer says about music], and Gilberte parrots Mme Cambremer's statement ironically: 'Relisez c'est un chef-d' œuvre!' [Rereading, that's rich] (Le Temps retrouvé, IV, 569; 3, IO4I, translation modified). Who is capable of rereading, what they read and how: these are the issues underlying the link between music, knowledge, and love. Within any second reading, like the second hearing, transference as a kind of false association may occur. Similar echoes of doubling back in order to recognize the return to a self within, on the other hand, signal the triumphant moments placed at the beginning and the end of the work.

The recapitulation of reading the self in writing turns out to involve explosive transferential material. The act of rereading, taken in its largest sense to encompass the reception of writing, art and music, begins the work of life writing in a transference between self and other-as-self. The ' $\mathrm{I}$ ' is found neither in identification nor fiction, but somewhere in between: between perception and thought, seeing 
and hearing, and their spiritual equivalents in art. It marks the points where time past and present, self and other coalesce to produce a narrator whose coherence comes out of a constant search and quest for the unity within disjunctive memory. While Jean Imbeault separates Freud and Proust by the context in which each worked - the difference between a man of letters and a man of science - and puts to use their work on memory, he nevertheless sees two areas in which their work overlaps: the split between perception and consciousness, on the one hand, and the focus on a centre for the perceiving subject in memory. I believe however that Imbeault comes closest to describing the process of moving from self-recognition to writing for Proust when he describes transference through dreamwork as thought. 'The Interpretation of Dreams is not, in the end, about dreams, but rather about the act of thinking. The properly Freudian way of interpreting dreams should rather be formulated thus: what is a dream for someone (let's say a human being) capable of thinking'; 'Transference is in the interval between . . . two narratives, life events on the one hand, dreams on the other'. ${ }^{\mathrm{I}}$

The narrator defines who he is by how he has arrived at his vocation, not how he will practise it. In order to love the work, as Sarah Kofman writes of Wagner and Nietzsche, 'the artist must 'forget' its conception (genèse). ${ }^{\text {I4 }}$ Such forgetting is realized in the misperception of writing in Le Figaro such that Marcel cannot 'see' that what he has written is his own writing until it is blotted out through forgetting, then restored through recognition in otherness. That is perhaps why in the final version of the scene, the bomb has been taken out of the mother's hands and scattered throughout the text at crucial moments when the narrator indicates an abrupt shift with the words 'tout à coup': for example, the sudden retroactive discovery that Wagner made of the unity of his work (III, 666-67); the extraordinary vision of Gilberte's eyes and the narrator's erroneous memory (I, I39); the rediscovery of the sonata in the midst of the septet. Significant memory involves sudden retrieval by the narrator:

le souvenir [...] nous fait tout à coup respirer un air nouveau, précisément parce que c'est un air qu'on a respiré autrefois, cet air plus pur que les poètes ont vainement essayé de faire régner dans le paradis et qui ne pourrait donner cette sensation profonde de renouvellement que s'il avait été respiré déjà, car les vrais paradis sont les paradis qu'on a perdus. (IV, 449)

[the returning memory [...] causes us suddenly to breathe a new air, an air which is new precisely because we have breathed it in the past, that purer air which the poets have vainly tried to situate in paradise and which could induce so profound a sensation of renewal only if it had been breathed before, since the true paradises are the paradises that we have lost.] (3, 903; emphasis added)

One commonly associates the words 'tout à coup,' or 'tout d'un coup,' with the ontologically significant moments of the mémoire involontaire, paradigms of suddenness. But a search of the novel in the ARTFL database led to a startling discovery. The two phrases occur 8I9 times, of which perhaps 200 should be discounted as repetitions. For example, accumulated experience can be wiped out in one moment, as in the following example: 'Tout à coup mon anxiété tomba, une félicité m’envahit comme quand un médicament puissant commence à agir et 
nous enlève une douleur: je venais de prendre la résolution de ne plus essayer de m'endormir sans avoir revu maman, de l'embrasser' [Then, suddenly, my anxiety subsided, a feeling of intense happiness coursed through me, as when a strong medicine begins to take effect and one's pain vanishes: I had formed a resolution to abandon all attempts to go to sleep without seeing Mamma, and had made up my mind to kiss her] (Du côté de chez Swann, I, 32; I, 34; emphasis added). Or experience can return dramatically through memory: 'd'avoir laissé mourir ma grand'mère; surgissant tout à coup du fond de la nuit où elle semblait à jamais ensevelie et frappant comme un Vengeur, afin d'inaugurer pour moi une vie terrible, méritée et nouvelle' [for having allowed my grandmother to die; perhaps rising suddenly from the dark depths in which it seemed forever buried, and striking like an Avenger, in order to inaugurate for me a new and terrible and only too well-merited existence] (Sodome et Gomorrhe II, III, 499; 2, II52; emphasis added). Memories can become themselves an event (here referring to the ravages of jealousy): 'il arrive que des souvenirs, postérieurement à tout événement, se comportent tout à coup dans notre mémoire comme des événements eux aussi, souvenirs que nous n'avions pas éclairés jusquelà' [it may happen that memories subsequent to any event suddenly materialise and behave in our minds as though they too were events, memories which hitherto we had never explored] (La Prisonnière, III, 594; 3, 82; emphasis added). This capacity for overlay and dislocation makes irreversible time reversible in thought and art: 'l'avenir, mais même le passé, qui ne se réalise pour nous souvent qu'après l'avenir, et nous ne parlons pas seulement du passé que nous apprenons après coup, mais de celui que nous avons conservé depuis longtemps en nous et que tout d'un coup nous apprenons à lire' [the future alone, but even the past, which often comes to life for us only when the future has come and gone - and not only the past which we discover after the event but the past which we have long kept stored within ourselves and suddenly learn how to interpret] (La Prisonnière, III: 594; 3, 82).

This form of deciphering memories as events, and events as memories, comes to constitute a self projected as a whole through the fissured parts. Such disjunctive moments are not so much the exception as a constant in the cognitive process of the narrator: the repeated moves from peripeteia to recognition. These involve, as Terence Cave has convincingly shown, the acquisition of knowledge and recognition as the quintessence of all narrative. ${ }^{\mathrm{IS}}$ Things will change not according to reason or perception, but by seismic shifts or reversal of direction, such that one might conclude about the accumulations and explosions in the novel, in the move from da capo al fine, as T. S. Eliot implicitly did:

$$
\text { music heard so deeply }
$$

That it is not heard at all, but you are the music While the music lasts.

(T. S. Eliot, 'The Dry Salvages', Four Quartets)

\section{Notes to Chapter 7}

I. This essay was previously published in Proust in Perspective: Visions and Revisions, ed. by Armine Mortimer and Katherine Kolb (Urbana: University of Illinois Press, 2002). 
2. For an extensive history and analysis of the poetics of recognition, see Terence Cave, Recognitions: A Study in Poetics (Oxford: Oxford University Press, I990).

3. References to Contre Sainte-Beuve are to the Fallois edition (Paris: Gallimard, I95I); trans. by Sylvia Townsend Warner as By Way of Sainte-Beuve (London: Chatto and Windus, I958). The I987 Pléiade edition of the Recherche gives four esquisses, two of which are the same as the text published by de Fallois. See Esquisses XI, XII, in IV, 668-7I.

4. My thanks to Antoine Compagnon for his comments about the erotics of this passage.

5. Françoise gives herself over 'à cet art de la cuisine pour lequel elle avait certainement un don' ['to that art of cooking at which she was so gifted'] (I, 437; I, 480). See my essay, 'The Anxiety of Art and the Gift of Writing', in The World and its Rival: Essays on Literary Imagination in Honor of Per Nykrog, ed. by Kathryn Karczewska and Tom Conley (Amsterdam: Rodopi, I999), pp. $249-63$.

6. The note to this page signals a passage from Cahier 27 which announces the doubling of Swann: 'Le motif était fini mais il allait revenir une dernière fois et Swann, sentant qu'il allait revenir, de nouveau un sanglot souleva sa gorge. Car l'attente de quelque chose même de médiocrement émouvant est en elle-même émouvante, car l'esprit qui attend ce retour sait qu'il va recevoir un choc, s'aperçoit lui-même comme un auditeur à qui il va causer une forte impression [...] De même que quelqu'un qui lit haut ou qui chante à quelqu'un quelque chose d'émouvant, quand arrive le moment où la parole émouvante va venir, il sent que non seulement son auditeur va être ému, mais va penser qu'il l'est lui-même; et dans ce retour sur lui-même et au moment où il prononce les mots émouvants, son œil se mouille, sa voix tremble du sanglot de pitié que l'auditeur doit éprouver pour lui; ainsi Swann dédoublé s'apercevait comme cet auditeur à qui il savait que le retour de la phrase devait paraître émouvant et émouvant pour lui aussi' [The theme had come to an end but it was going to return one last time and Swann, sensing it was going to return, was overcome once again by a sob. For expectation, even of something only mildly moving, is itself moving, because the mind that is expecting this return knows that it is going to receive a shock and perceives itself as a listener upon whom the return will cause a strong impression. [...] Just as someone reading aloud or singing something moving to someone else, at the point where the moving words are about to come, feels not only that his listener will be moved, but will also think that he is himself; and in this turn inward upon himself and in the moment where he pronounces the moving words, his eye moistens, his voice trembles with the sob of pity that the listener must feel for him; so Swann, doubling himself, perceived himself as this listener for whom he knew that the return of the motif must seem moving and moving also for him] (fols. $48^{\mathrm{r}}-5 \mathrm{O}^{\mathrm{r}}$, I, I24I, n. 2).

7. Gérard Genette, 'Métonymie chez Proust', in Figures III (Paris: Seuil, I972), p. 56

8. Gilles Deleuze, Proust and Signs, trans. by Richard Howard (New York: G. Braziller, I972), p. 25 , p. 29.

9. Walter Benjamin, 'The Image de Proust', in Illuminations, ed. by Hannah Arendt, trans. by Harry Zohn (New York: Schocken, I968), pp. 20I-I6 (p. 203).

Io. Philippe Sollers, L'Eil de Proust. Les Dessins de Marcel Proust (Paris: Stock, I999), p. 2 I.

II. Philip Kolb recorded on his fiches a certain number of incidents involving bombs: 'A bomb at the maison Rothschild, yesterday, rue Lafitte.' Figaro, 6 September I895; 'Attack against the baron de Rothschild 'yesterday' at Trouville. An exploding envelope.' Figaro, 25 August I895; 'A bomb explodes, rue de Rohan, after the gala at the Opera.' Almanach Hachette, I907, p. 258; Illustration, anarchist attack against Loubet, the President of the Republic, and Alfonso XIII, king of Spain; 'a bomb at the Madeleine.' Journal des Goncourt, 9 vols (Paris: Fasquelle, I896-I907), IX, 200.

12. The New Grove Dictionary defines da capo as follows: '(It.: 'from the head'). An instruction, commonly abbreviated D.C., placed at the end of the second (or other later) section of a piece or movement, indicating that there is to be a recapitulation of the whole or part of the first section. The word 'fine' (end) or a pause sign marks the point at which the recapitulation ends' (p. I43). 'The da capo aria became the standard form in the cantata and the opera seria of the late Baroque period. [...] Sometimes sets of variations (e.g. Bach's Goldberg Variations) had a da capo of the theme at the end.' (Signed 'Jack Westrup'.) By the nineteenth century with Wagner, 'one category of changes worked in the direction of avoiding small musical units; ends of phrases 
were obscured by eschewing conventional cadences, and arias and ensembles were merged into the flow of action. [...] Wagner experimented with merging the acts into one continuous unit, the opera' (p. 566). According to The New Harvard Dictionary of Music, 'The da capo aria came under increasing criticism from Gluck and others by the final third of the I8th century, for both musical and dramatic reasons. In some instances, it became merely a virtuoso singer's plaything - not only undramatic but antidramatic. [...] Arias were also constructed along the lines of instrumental movements, in binary, sonata, or rondo forms' (p. 49).

I3. Jean Imbeault, Mouvements (Paris: Gallimard, I997), p. 83; p. 86.

I4. Sarah Kofman, L'Imposture de la beauté (Paris: Galilée, I995), p. 95.

I5. Cave, Recognitions, pp. I-6. 